\title{
Valuation of Range land Resource in Pastoral and agro pastoral Areas of Debub Omo Zone, SNNPR, Ethiopia
}

\author{
Kutoya Kusse*, Yidnekachew Alemayehu and Kebede Kassu \\ Southern Agricultural Research Institute, Jinka Agricultural Research Center Socio-economic researchers, Ethiopia
}

Submission: September 18, 2018; Published: September 28, 2018

*Corresponding author: Kutoya Kusse, Southern Agricultural Research Institute, Jinka, Ethiopia, email: getahunkusse@gmail.com

\begin{abstract}
A survey was conducted in Dasenech and Benna-Tsemay districts of the South Omo zone of Southern Ethiopia, with the objectives of identifying determinants of WTP for Rangeland rehabilitation in Pastoral and agro pastoral area, to estimate the economic value of range lands in pastoral \& agro pastoral areas and to identify major constraints facing pastoral and agro pastoral in the study areas. The information was gathered through group discussions and using a structured questionnaire. The major livestock production constraints were drought, feed and water shortage and animal health problems. There are no range improvement practices undertaken to improve the condition of the rangelands. Mobility is the first measure taken to solve shortage of livestock feed and water but many of the pastoralists replied that they face many problems during migrations. In conclusion, the indigenous knowledge of the pastoralists about range-livestock management and their environment should be incorporated while planning range-livestock development projects for the study districts.
\end{abstract}

Keywords: Pastoralism; Rangeland; Rangeland Management; Willingness to Pay

\section{Introduction}

The Greater Horn of Africa region is home to a significant number of pastoralists whose livelihood system is based on production in the arid and semi-arid lands. These areas are characterized by low and erratic rainfall, high temperatures, and consequently, high evaporation rates. Across the region there have been tightening cycles and intensities of drought and flooding, and concomitant problems such as food insecurity, human and livestock diseases and other crises. These have challenged the human capacity to cope, eroded the livestock, natural resource and other asset bases and gradually diminished the capacities of pastoralist communities to rebound. These impacts are exacerbated by other pressures, such as loss of land, widespread and endemic resource-based conflict, poor infrastructure and service provision, and general marginalization. The result is a state of vulnerability and often 'crisis' within pastoralist communities and areas [3].

Pastoralism is the one of the predominant livelihoods of east Africa and the Horn. It contributes significantly to national economies and can conserve fragile natural resources. Yet pastoralists remain socially and economically marginalized and have little or no representation in local and national government. Governments in the region continue to hold that Pastoralism is unsustainable and a barrier to development [4]. Ethiopia's pastoralist community of ten million people occupies 61 percent of the total land mass. The 29 nationalities and ethnic groups inhabit land with natural resources and a wealth of cultural and traditional heritage that remains largely untapped. Ethiopian pastoralists raise a large portion of the national herd, estimated at 42 percent of the cattle, 7 percent of the goats, 25 percent of the sheep, 20 percent of the equines and all of the camels. However, pastoralist communities are often unable to harness the immense resources of their land due to internal and external pressures related to land tenure and use. This is because the policies that relate to the use and access of pastoral land do not adequately promote pastoral rights [5].

Some of the major positive scenarios for pastoral economies development in the next 15-20 years comprised of

a) Irrigation and other land use versus Pastoralism;

b) Land tenure and the importance of mobility and flexibility;

c) Settlement and the issues associated with pastoral sedentarization; and

d) Trade and especially the question of overseas export versus regional/unofficial cross-border and domestic marketing [6].

Pastoral communities' participation in decision making for environmental monitoring is regarded as one of the pillars of sound rangeland management. There are three assumptions involved. 
Firstly, it is acknowledged that pastoralists have their own experiences and knowledge, which they have used for generations to manage the rangelands. Secondly, it is assumed that their knowledge is measurable and comparable across communities. Thirdly, it is assumed that their knowledge and its outcomes can make an important contribution to the development of local policies. Nevertheless, rangeland researchers have generally not incorporated into their research how this knowledge is generated and may be applied. Its usefulness in complementing existing scientific knowledge for the assessment and monitoring of rangelands is therefore little understood. Indeed, there is limited information on the comparability of indigenous knowledge across pastoral communities in different regions of Africa using appropriate frameworks for comparative regional studies $[1,2]$.

Even if the pastoralists held majority land coverage of all the country cultivable land in general and southern Ethiopia in particularly, its productivity, utilization efficiency and effectiveness, total yield per hectare is still very low and so lower as compared to any other East African Countries level of productivity due to various reasons. Some of the major constraints that hindered not to use pastoralist range land are: lack of appropriate management option, incapability of measuring total economic value of pastoralists and its difficulty of measurement, low attention given by government to the sector due to absence of economically measured and quantifiable information on the sector, lack of best practices and utilization system adopted, lack of appropriate technologies that help to boost the productivity level and undervaluation/underestimation of the economic, social and environmental role of Pastoralist that stems from the lack of appropriately collected organized and assembled database, Erratic rain fall, high temperature, lack of awareness, weak linkage between research institute, universities, nongovernmental organization, Invasion of range and grazing lands by unwanted, dangerous, unpalatable and hardy plant species. Accordingly, Debub Omo Zone is one of the Zones in southern region which faces the same problem that are mentioned above. Therefore, in order to characterize the listed and other related constraints and potentials, find out economic value of pastoralists and so as to forward scientific information for further research and development intervention and remedial policy measures to be taken, it is timely and indispensable to undertake research over economic value of pastoralists and determinant of willingness to pay for rehabilitation of range land.

\section{General objective of the study}

A) To valuate range land productivity in pastoral and agro pastoral areas.

\section{Specific objective}

a) To identify determinants of WTP for Rangeland rehabilitation in Pastoral and agro pastoral area.

b) To estimate the economic value of range lands in pastoral \& agro pastoral reas. c) To identify major constraints facing pastoral and agro pastoral in the study areas.

\section{Methodology \\ Description of The Study Area}

South Omo zone is one of the 14 administrative zones found in the Southern Nations, Nationalities, and People's Regional State in Ethiopia. It is located at $4^{\circ} 27^{\prime}-6^{\circ} 26^{\prime}$ north and $34^{\circ}$ 5 5 ' $-37^{\circ}$ $49^{\prime}$ east bordering Gamogofa and Keffa zones; Konta and Besketo special districts to the north; Konso and Derashe special districts to the east; Borana zone to the southeast; Kenya to the south; Sudan to the southwest, and Bench Maji zone to the west. The total land area of the zone is $22,360.76 \mathrm{~km}^{2}$ and lies at an altitude ranging from 380 to 3,300 m.a.s.l [1].

The study was implemented in the major pastoralist and agro pastoralist areas of Dasenech and Benatsemay woredas in South Omo Zone of SNNPR. From each Woreda, three kebeles were selected according to statistical criteria and secondary update data gathered from the respective Woreda offices. Dasenech Woreda is found in South Omo Zone in SNNP and bordered by Kenya in the South, Salamago Woreda in the North and Hammer Woreda in the East. It was lied astronomically $\left(5^{\circ} .14 \mathrm{~N}\right.$ latitude, $36^{\circ} .44$ E longtude) and is $225 \mathrm{~km}$ from Jinka, the Capital city of South Omo Zone. Whereas BenaTsemay is one of the woredas in Debub Omo Zone of Southern Nations, Nationalities, and Peoples' Region of Ethiopia. It is named after Banna and Tsamai people who are living at this woreda. Part of the Debub Omo Zone, BenaTsemay is bordered on the south by Hamer, on the west by Selamago, on the north by Bako Gazer and Malle, on the northeast by the Dirashe woreda, on the east by the Konso woreda, and on the southeast by the Oromia Region; the Weito River separates it from Konso woreda and Oromia Region. Western part of this woreda is included in the Mago National Park. The administrative center is Key Afer. BenaTsemay was part of former Hamer Bena woreda.

\section{Source and Method of Data Collection}

Primary data was collected from the field survey to determine the willingness to pay, the economic benefit of rehabilitation of the rangelands, while secondary and abstract data was used to simulate the management systems and the dynamic benefits accruing from each system.

\section{Sampling Techniques and Sample Size}

The study used multistage sampling technique, first the study districts were selected purposively based on their rangeland using practice. also the study kebeles from each district were selected purposively in relation to their number of livestock and utilization. Then the number of sample household respondents from each kebele selected proportionally to the total number of households in each kebele. finally each sample household was selected by simple random sampling. A total of 120 sample households were covered during the survey. 


\section{Data Analysis}

The primary data collected from the survey was analyzed by computer using SPSS software to estimate the WTP and establish the factors that influence the likelihood of the WTP responses. The major data categories collected at the survey level includes economic values of rangeland management options and the major problems facing pastoralists.

\section{Logit Model}

was used in order to explain the explanatory variable relation with dependant variables. In addition to these coefficient of determinations of economic variables or correlations coefficients was estimated multi correlation of variables checked. The dependant variable Estimated was Willingness to pay for range land rehabilitation in the study area and Explanatory variables: WTP $=f$ (age, Sex, Marital status, education level, economic status, Source of livelihood, Source of income, Type of housing Rangeland ownership and Source of water).

\section{Results and Discussion}

\section{Demographic and Socio-economic Characteristics of Respondents}

Table 1: Sex, Educational Level and Marital Status of Sample Respondents.

\begin{tabular}{|c|c|c|c|}
\hline \multicolumn{2}{|c|}{ Variables } & $\begin{array}{c}\text { Respondents } \\
\text { (N=120) }\end{array}$ & Percentage \\
\hline Sex & Male & 103 & 85.8 \\
\hline & Female & 17 & 14.2 \\
\hline Educational level & Illiterate & 100 & 83.3 \\
\hline & $\begin{array}{c}\text { Able to read and } \\
\text { write }\end{array}$ & 3 & 2.5 \\
\hline & First cycle & 3 & 2.5 \\
\hline & Primary school & 10 & 8.3 \\
\hline & Secondary school & 3 & 2.5 \\
\hline & $\begin{array}{c}\text { Diploma and } \\
\text { above }\end{array}$ & 1 & 0.8 \\
\hline Marital Status & Married & 117 & 97.5 \\
\hline & Single & 3 & 2.5 \\
\hline
\end{tabular}

Source: Survey Data Result.

Attempts were made to collect information on demographic characteristics of the sample survey households to provide information on some of the key variables for the study area. The variables examined in this section were household heads' sex, age, education level, marital status and family size. The results of the study (Table 1) indicate that $85.8 \%$ of sample households were male headed households. The remaining $14.2 \%$ of sample households were female headed households. In terms of marital status, whereas $97.5 \%$ of sample households were married and only $2.5 \%$ of households were single. As Table 1 depicts, the educational background of the sample household heads is believed to be an important feature that determines the readiness of household heads to accept new ideas and innovations. More educated farmers are expected to adopt new technologies to increase their range land productivity. Based on education categories the data indicated that $83.3 \%$ of the sample respondents were illiterate, $2.5 \%$ able to read and write, $2.5 \%$ of the respondents attained first cycle education, while $8.3 \%$ were primary school. The remaining $2.5 \%$ and $0.8 \%$ of the sample respondents attained secondary education and certificate and above respectively (Table 2 ).

Table 2: Age category, Family size and Economic status of sample respondents.

\begin{tabular}{|c|c|c|c|}
\hline \multicolumn{2}{|c|}{ Variables } & $\begin{array}{c}\text { Respondents } \\
(\mathbf{N = 1 2 0 )}\end{array}$ & Percent \\
\hline & $<25$ & 1 & 0.8 \\
\hline & $25-35$ & 46 & 39.2 \\
\hline Age of respondents & $36-45$ & 41 & 33.3 \\
\hline & $46-55$ & 27 & 22.5 \\
\hline & $>55$ & 5 & 4.2 \\
\hline Family size & $\leq 5$ & 40 & 33.3 \\
\hline & $10-$ May & 56 & 46.7 \\
\hline & $>10$ & 24 & 20 \\
\hline Economic status & Low & 77 & 64.2 \\
\hline & Medium & 37 & 30.8 \\
\hline & High & 6 & 5 \\
\hline
\end{tabular}

Source: Survey Data Result.

\section{Livelihood and Income Source of Pastoralists and Agro- pastoralists}

The livelihood status of the pastoralists and agro-pastoralist in the study area differ from district to district in which the study was conducted, the study was conducted in Dasenech and BenaTsemay districts of pastoralist and agro-pastoralists respectively. Pastoralists relay on Livestock rearing only and agro-pastoralists depends both on Livestock rearing and Crop production. The income source for the two categories of community were from sale of livestock and their products, from sale of crops they produce and that of range land resources in small scale. Figure 1 shows the major source of livelihood in the study area.

From Figure 1 above about $67.5 \%$ of the sample respondents responded that their livelihood depends on both livestock and crop production, $5 \%$ depends on crop production while the rest $27.5 \%$ of the sample respondents depends on livestock rearing. This shows that majority of the respondents depends on both crop and livestock production where as the minority depends on crop production. The other their source of income illustrated in Figure 2 below. As indicated in Figure 2 above about 49.2\% of the sample respondents get their income from both livestock, livestock products and crop, 45\% from livestock and their product only where as $5.8 \%$ from crop sale only. It shows that majority of the sample respondents get income from both crop and livestock and their products, while the minority gets their income from crop sale only. 


\section{International Journal of Environmental Sciences \& Natural Resources}

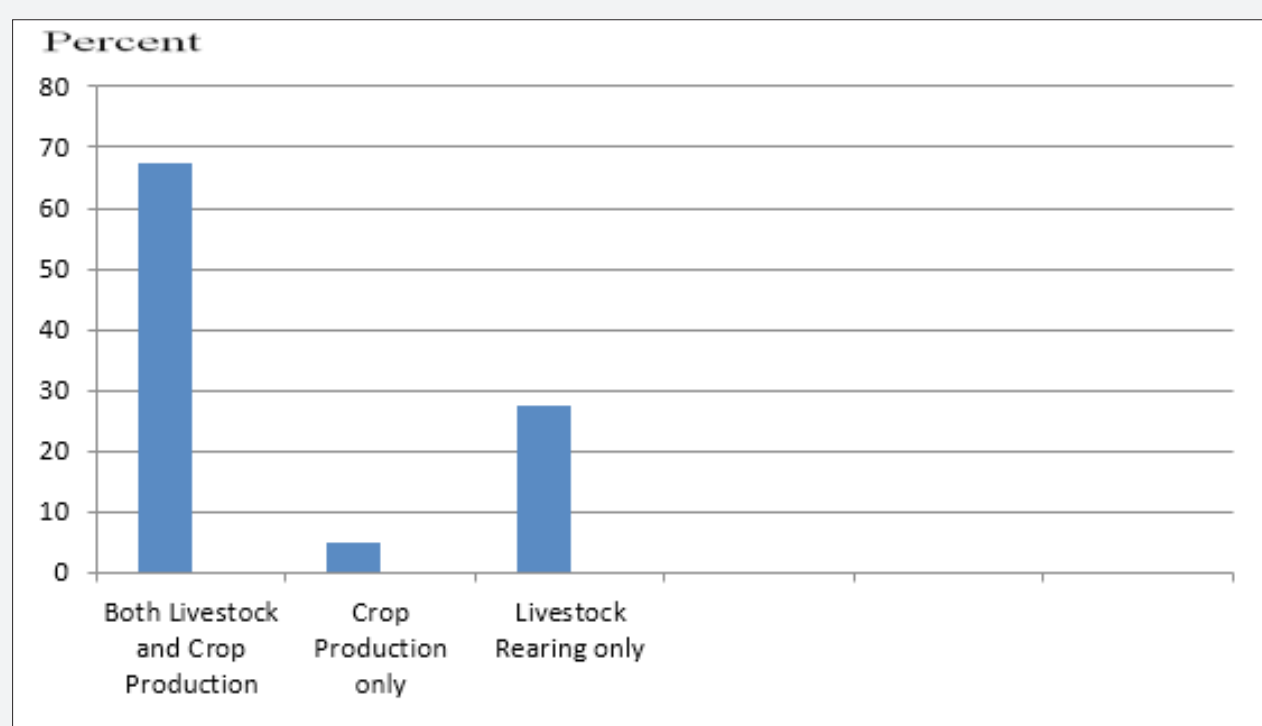

Figure 1: Sources of Livelihood in the Study Area.

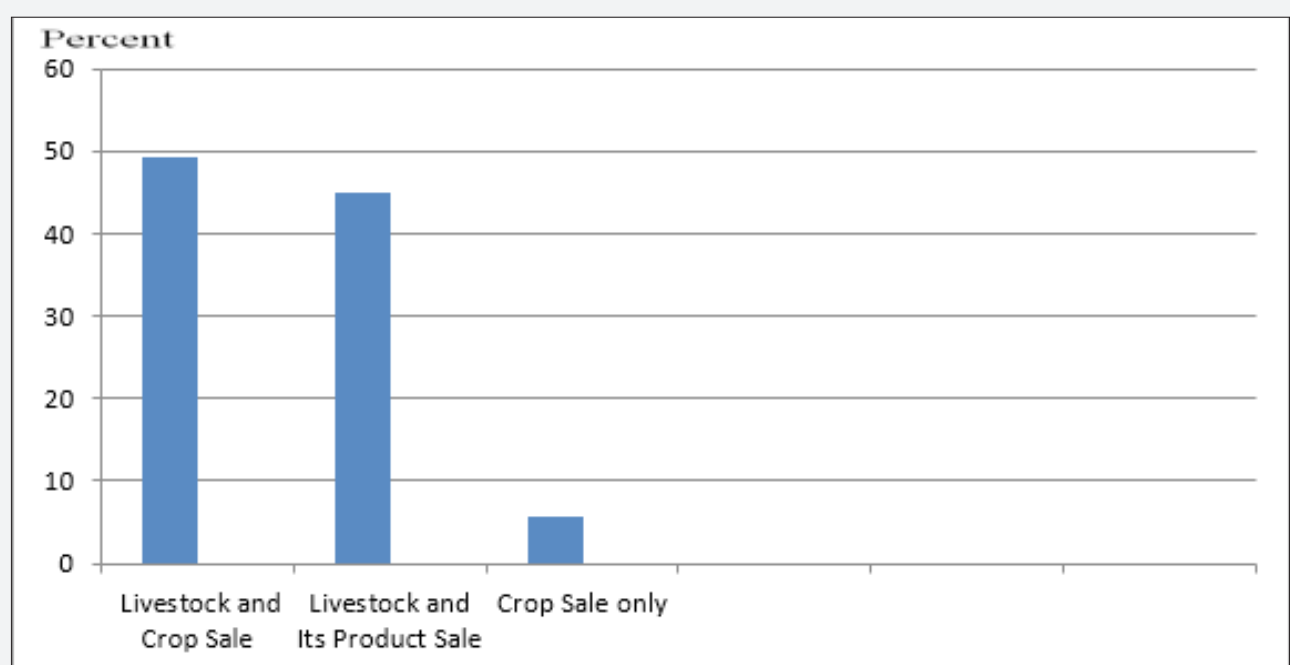

Figure 2: Source of Income in the Study Area.

Results of the study also shows that $83.3 \%, 8.3 \%$ and $8.3 \%$ of the sample respondents across the study area had permanent, semi permanent and temporary type of houses respectively. The ownership status of grazing land of the respondents in the study area shows $93.3 \%$ have their own grazing land where as $6.7 \%$ haven't their own grazing lands. The minimum and maximum amounts of grazing land in the study area were 0.12 and 8.0 hectare respectively with an average holding of 1.93 hectare. About $63.3 \%$ of the sample respondents from a total of 120 respondents in the study area responded that over the past two decades indigenous plant species like "Woyira", "Wanza" and the others were disappeared and also the range land productivity were reduced due to agricultural land expansion, overgrazing, declining of rain fall, high run off and due to the abandonment of natural water harvesting.

\section{Feed sources and Range Land Management}

Natural pastures, woody plants and crop residues were the major feed sources for livestock in the study area. The availability of crop residues in the study area was low such as straw from maize, sorghum and teff, which were served as a fed mainly during the dry season. As most of the land was covered with woody vegetation, trees and shrubs they were important sources of livestock feed throughout the year. The respondents experienced a critical feed shortage during long dry seasons. So strategies for coping with feed shortages in the study area includes; move to new area, choice to cell animals, supplementation of crop residues and buy of feeds. Range land management practice was a recent innovation, which were used to overcome the major constraints of pastoralists or agro pastoralists to enhance production and productivity. Ways of sustainable range land management and adoption to dry seasons were presented in Table 3 below.

Health and productive rangelands are vital to all users and uses. To enhance this introduction of appropriate measures to control rangelands within the natural limits will be crucial in halting the degradation of rangelands. In Table 3 above the results of the study shows that $67.5 \%$ of the sample respondents 


\section{International Journal of Environmental Sciences \& Natural Resources}

uses rational grazing, while $27.5 \%, 3.4 \%, 0.8 \%$ and $0.8 \%$ uses manipulating the stocking rate, over sowing of improved forage seeds, fertilizer inputs and use of weed herbicides respectively. Enclosures were usually located around the homestead and farmlands and were used mainly for dry season feeding of lactating cows, calves, draught oxen and weak and sick animals. Drought (i.e., shortage of rainfall), bush encroachment, poor productivity and lack of proper management of enclosures were considered major constraints to production. To react with this constraints bout $54.2 \%$ of the sample respondents were transhumance moving their livestock seasonally in order to exploit areas remote from their permanent settlement sites. $25 \%$ choice to sell animals, while 20.8\% were used to buy feeds for their livestock. A type of cattle keeping system familiarized in the study area were, $63.3 \%$ of the respondents responded that they use private type of cattle keeping system, $19.2 \%$ were open access, while $17.5 \%$ were communal type of keeping system.

\section{Sources of Water}

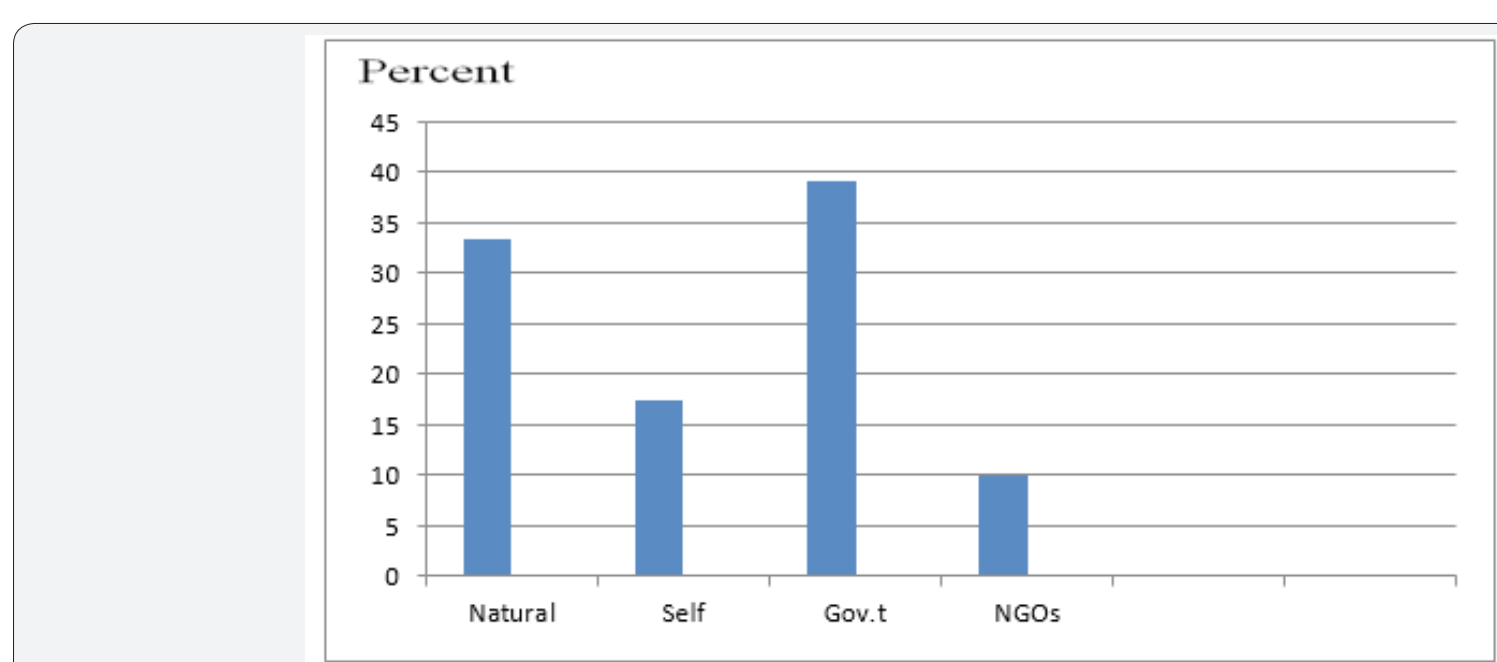

Figure 3: Source of Water in the Study Area.

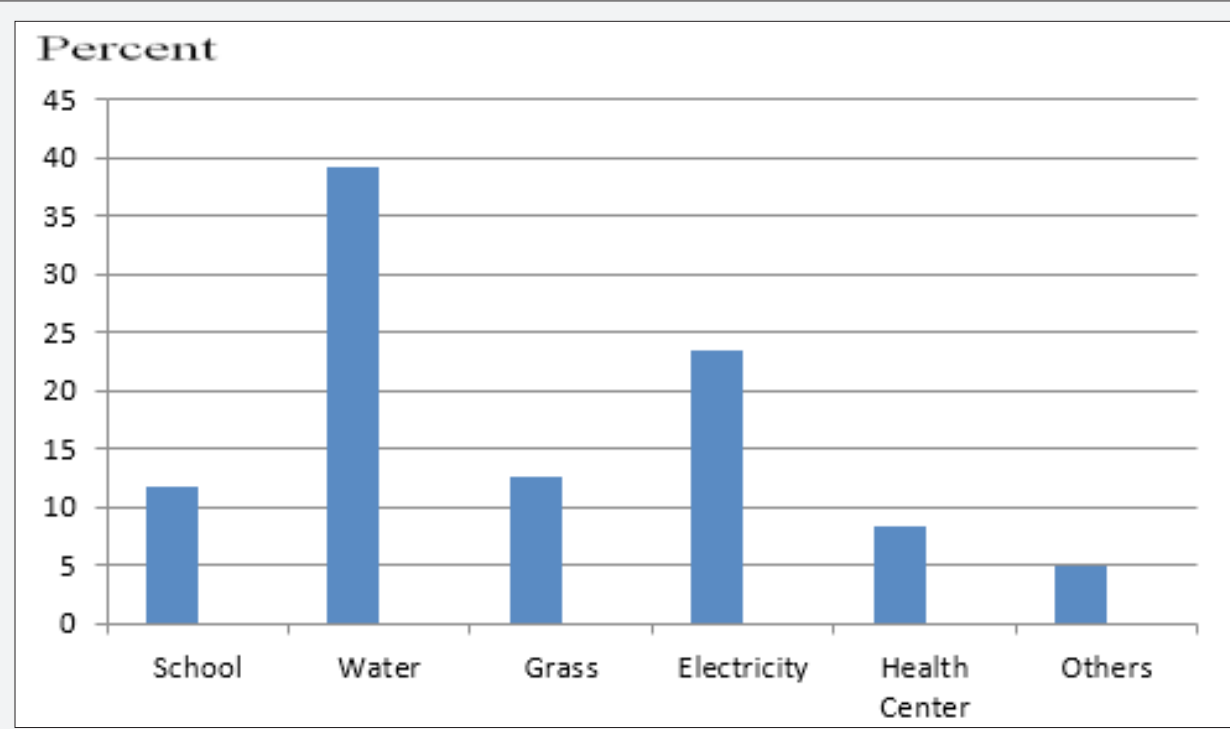

Figure 4: Ranking of Respondents Needs. 
The study shows that the majority source of water in the pastoral and agro pastoral rangeland areas were government, natural, self and NGOs sources. However the majority of cattle keepers in the study area get water from government sources while natural source is the second, self source is the third and NGOs is the last one as presented in Figure 3 below. The result shows that $39.2 \%$ was from government, $33.3 \%$ from natural source while $17.5 \%$ and $10 \%$ were from self and NGOs respectively. Government source takes the highest part, but still now it is not enough. So to improve the welfare of the people and increase livestock production government should have to invest more in provision of water in these areas. It is also very important that water harvesting technologies and watershed management are developed and irrigation should be encouraged in districts like Dsenech in which one of the biggest rivers (Omo River) found. The respondents in the study area were asked to put their needs in the order of importance if the government was to provide them. The needs of the respondents were presented according to their importance in Figure 4. The results of the study indicate that water is one of the most important inputs for livestock production and also one of the reasons why the pastoralists move from place to place is because they are looking for water for their livestock and own consumption. According to this study $39.17 \%$ of the respondents ranked water as first, $23.33 \%$ electricity as second and the others $12.5 \%, 11.67 \%, 8.33 \%$ and $5 \%$ ranked grass, school, health center and others respectively.

\section{Management and Utilization of rangeland and its re- sources}

The development of good rangeland management and utilization in the private and communal rangelands provide the way of overcoming the open access grazing problems in the private and communal rangelands and allows coordinated and flexible rangeland use and optional stocking rates. For rangeland users, regulatory policy might involve environment of destocking to allow rangeland to recover from excessive continuous grazing pressure. Practicing such kind of managements and utilization system is not considered in the study area due to lack of knowledge about effective utilization and management of rangelands. Therefore, training stockholders and good extension service by government and NGOs in the principles of good rangeland management is needed.

\section{Rangeland Use Conflict}

The term conflict refers to ongoing disputes between various ethnic groups over the access to scarce rangeland resources in the study area. This dispute arises between Dasenech and Kenya around border of Turkana Lake, Hammer and Dasenech Worda's ethnic groups the other between Bena-Tsemay and Mago National park keepers, over the last two years the conflicts increased especially in the year 2009 due to the drought happen over the whole country especially in the pastoral and agro pastoral of the country. It occurs when the pastoralists or agro pastoralists search for water, grass and settlement.

\section{Values of Rangelands}

The concept of rangeland values underlies a Pastoralists way of life that adapts to marginal environments, characterized by climatic uncertainty and low-grade resources. It has considerable economic value and latent potential in the dry lands, and is central to the livelihoods and wellbeing of millions of the world's poor. However, the state of knowledge regarding this sector of the economy is weak. Pastoral system is not simply a mode of livestock production, rather a complex system that needs adequate and careful valuation. They are also consumption systems that support millions of mobile pastoralists globally. They are natural resource management systems that provide a wide range of services and products that are nationally and globally valued, such as fire wood (charcoal), honey, fruits, medicinal plants, raw materials for agriculture gum, home furniture and housing materials. These values of rangeland in the study area are depicted in Table 4 below.

Table 4: Values of range land in the study area.

\begin{tabular}{|c|c|c|c|}
\hline Rangeland Resources & $\begin{array}{c}\text { Initial cost } \\
\text { (cost incurred) }\end{array}$ & $\begin{array}{c}\text { Estimate } \\
\text { market } \\
\text { value }\end{array}$ & $\begin{array}{c}\text { Net } \\
\text { income }\end{array}$ \\
\hline Firewood (charcoal) & 919.9 & 8299.9 & 7580 \\
\hline honey & 3579.98 & 26060.19 & 22480.21 \\
\hline Fruits & 100 & 650 & 550 \\
\hline Medicinal plants & 502 & 3986.88 & 3488.88 \\
\hline Raw materials for agri- & 3349.94 & 11639.9 & 8289.69 \\
\hline culture & 50 & 720 & 670 \\
\hline Gum & 4005 & 30055.2 & 26050.2 \\
\hline Home furniture & 8439.9 & 41474.04 & 33034.14 \\
\hline Housing materials & & & \\
\hline
\end{tabular}

Rangelands are the most extensive ecosystems globally, covering approximately 70 percent of the world surface area and providing many economic values to the pastoral community. As indicated in Table 4 above the net income from firewood (charcoal) is $7580.00 \mathrm{ET}$, that of honey is $22480.21 \mathrm{ET}$ and the others 550.00 ET from fruits, 3488.88 ET from medicinal plants 8289.69 ET from raw materials for agriculture, 670.00 ET from gum 26050.20 ET from home furniture, 33034.14 ET from housing materials respectively.

\section{Willingness to pay for the rangeland improvement}

To improve the rangeland status in the study areas, all respondents were asked if they were willing to pay when a program intended to rehabilitate the range land in the study areas. Grass was replanted and permanent trees were also planted in the area to provide shades for their animals. Improved forages were introduced, unwanted invasive and unpalatable plant species were cleared out from the rangeland, palatable and highly nutritious feeds (legume, browse or grass species) were over-sowed, permanent sources of water were constructed, so that they were no longer need to move long distances to water their animals. However when these things were put in place, they need improvement works so that they last forever. To contribute 
this improvement program every person in the community were asked to contribute his/her labor force/ money per month/ year since this resource belongs to them. According to this study the results show that $87.5 \%$ of all respondents were willing to pay for improvement of rangeland. Among the respondents who are willing to pay for the improvement program about $66.4 \%$ were participate by contributing their labor, while $33.6 \%$ were participate by contributing money. also from those who want to participate in money values about $80.6 \%$ were willing to pay the money in cash was as $19.4 \%$ were in kind. Table 5 below shows means of contribution and the amount of cash/labor they are willing to contribute.

As indicated in the Table 5 above the respondents of the two woredas responded that some of them were participate by contributing money while the others were by labor. From those respondents who were willing to contribute money was from Ocholoch the minimum amount of birr is 20.00 ETB and the maximum of 60.00 ETB with an average of 25.25ETB, Nikiya minimum 5.00ETB and the maximum of 20.00ETB with an average of 10.12 ETB, Hado minimum 10.00 ETB and the maximum of 30.00 ETB with an average of 14.40 ETB, Sitinba minimum 10.00 ETB and the maximum of $25.00 \mathrm{ETB}$ with an average of $13.90 \mathrm{ETB}$, Gurimamero minimum 20.00 ETB and the maximum of 100.00ETB with an average of 32.33ETB and that of Mukecha minimum 7.50 ETB and the maximum of 50.00 ETB with an average of 20.50 ETB. While for those respondents who were willing to contribute their labor from Ocholoch the minimum amount of labor day is 84 and the maximum is 300 with an average of 184.6, Nikiya minimum 150 and the maximum of 270 with an average of 162.9, Hado minimum 130 and the maximum of 260 with an average of 150.8 , Sitinba minimum 18 and the maximum of 102 with an average of 52.3, Gurimamero minimum 24 and the maximum of 80 with an average of 48.6 and that of Mukecha minimum 48 and the maximum of 130 with an average of 74.2 labor days per year respectively.

Table 5: The amount of money/labor/year the respondents are willing to contribute for rangeland improvement program.

\begin{tabular}{|c|c|c|c|c|c|c|c|}
\hline \multirow{2}{*}{ Name of woreda } & \multirow{2}{*}{ Name of kebele } & \multicolumn{3}{|c|}{ Amount of cash in ETB/year } & \multicolumn{3}{|c|}{ Amount of labor/year } \\
\hline & & Min & Max & Mean & Min & Max & Mean \\
\hline \multirow[t]{3}{*}{ Dasenech Woreda } & Ocholoch & 20 & 60 & 25.25 & 84 & 300 & 184.6 \\
\hline & Nikiya & 5 & 20 & 10.12 & 150 & 270 & 162.9 \\
\hline & Hado & 10 & 30 & 14.4 & 130 & 260 & 150.8 \\
\hline \multirow[t]{3}{*}{ Bena-Tsemay Woreda } & Sitinba & 10 & 25 & 13.9 & 18 & 102 & 52.3 \\
\hline & Gurimamero & 20 & 100 & 32.33 & 24 & 80 & 48.6 \\
\hline & Mukecha & 7.5 & 50 & 20.5 & 48 & 130 & 74.2 \\
\hline
\end{tabular}

\section{Factors Affecting Willingness to Pay}

Table 6: Likelihood estimates of the logit model for WTP ( $N=120$ respondents).

\begin{tabular}{|c|c|c|c|}
\hline Variables & Coefficients & Std Err & P-value \\
\hline Sex & -0.182 & 0.868 & 0.834 \\
\hline Age & -0.103 & 0.04 & $0.010^{* *}$ \\
\hline Marital status & 1.014 & 2.001 & 0.612 \\
\hline Education level & 0.912 & 0.225 & $0.000^{*}$ \\
\hline Economic status & 1.192 & 0.517 & $0.021^{* *}$ \\
\hline Source of livelihood & 1.426 & 0.701 & 0.42 \\
\hline Source of income & 0.598 & 0.773 & 0.439 \\
\hline Type of house & -2.358 & 1.142 & 0.39 \\
\hline Range land ownership & 5.601 & 1.151 & $0.000^{*}$ \\
\hline Source of water & -0.587 & 0.331 & $0.076^{* * *}$ \\
\hline
\end{tabular}

Log likelihood $=78.232{ }^{*},{ }^{* *},{ }^{* * *}$ indicates the variables are significant at 1, 5 and 10 percent respectively.

Logit model was used in order to explain the explanatory variable relation with dependant variables. A Binary logit model was used to analyze further and more socio-economic factors namely; sex of respondents, age of respondent, marital status, education, economic status, source livelihood, source of income, type of house and range land ownership number of cattle, in order to determine their influence on the likelihood of willingness to pay for the services in the proposed project. This addresses the first specific objective of the study. Table 6 presents the coefficients of the variables, standard error, and P values of the model.

The interpretations of the variables were as follows, it was found that increasing in age decreases the chance of willingness to pay by $10.3 \%$ and significant (P-value 0.010 ). This means when the age gets older and older the capacity also falls and the responsibility to manage the household is taken over and given to those who have the capacity to manage. The results also show that education which was represented by the number of years one stays in school increases the chances of WTP by $91.2 \%$ and also significant ( $p$-value 0.000 ). so education plays an important role in improving ones understanding and adoption of new technologies. In other hand the chance of WTP for respondent's increases by $11.92 \%$ when the economic status of the respondents is improved and also significant at ( $\mathrm{p}$-value 0.021) this means the respondents who have improved economic status were more willing to pay than that of lower economic status.

\section{Conclusion and Recommendations}

The study shows that rangeland is the base for the pastoralists and agro-pastoralists, in which more of the time their livelihood 
depends on livestock production for their income generation and consumption purposes. In their every days life they also get many economic values from the rangeland such as housing materials, home furniture, honey, firewood (charcoal), medical plants to make cultural medicines, agricultural raw materials, gum and fruits. To keep the sustainability of these rangeland resources and enhance the production and productivity of the livestock in the study area good and research supported management practices is needed, but still now traditional ways of using rangeland was practicing. Due to this traditional rangeland using mechanisms the production and productivity of rangeland declining from time to time and their live stocks are exposed to feed shortage risks. The pastoralists in the study area are mobile for the search of feed and water for their animals, so when they are searching they face many problems like conflict with in and out of the border, diseases and attack of their livestock by wild animals. The pastoralists or agro-pastoralists in the study area are looking for the government organizations or NGOs to help them and they also have high willingness to participate in the programs related to rangeland rehabilitation or management process by contributing their labor as well as money and also willing to stand along with any organization, who wants to support them. Logit model is employed to analyze the factors affecting the respondent's willingness to pay from these factors age and source of water affects willingness to pay negatively at 5 and 10 percent respectively, while rangeland ownership, level of education and economic status are affecting willingness to pay positively and significant at 1 and 5 percent respectively.

Pastoral development policies and strategies (such as range resources management and development, development infrastructure and services provisions) should be based on a sound knowledge of the current and potential, quantified and skilled technicians. In order to benefits from the huge economic, social and environmental values of rangelands that are discussed in this study, appropriate measures and support mechanism like proper rangelands use policy, rehabilitation of the pasture, water and vegetations, avoiding unpalatable woods and improper uses must be in place to alleviate the real challenges that are threats to the very survival of Pastoralists. In order to maximize the livestock and rangelands productivity the culture and techniques of mobility should be protected and promoted (supported). The traditional institutions have been eroded due to many interventions including the modern system of administrative rules and structures. For sustainable Pastoralism the positive aspects of traditional institutions and knowledge system need to be rehabilitated and be supported in a way they will be harmonious with the modern system of governance system and structures.

\section{References}

1. (2003) Districts Agricultural office (DAO), Anuual report, South Omo Zone, Jinka, Ethiopia.

2. Gufu Oba, Gufu Oba (2012) Harnessing pastoralists' indigenous knowledge for rangeland management: three African case studies, Noragric, Department of International Environment and Development Studies, Norwegian University of Life Sciences, PO Box 500, N-1432 Ås, Norway Pastoralism: Research, Policy and Practice 2: 1.

3. Helen Bushell, May (2010) Pastoralism demographics, settlement and service, provision in the Horn and East Africa; Transformation and opportunities, Oxfam GB in Kenya, Humanitarian Policy Group, Overseas Development Institute, 111 Westminster Bridge Road, London SE1 7JD, United Kingdom.

4. Naomi Kipuri, Andrew Ridge well (2008) Minority Rights Group International, Adouble Bind: The Exclusion of Pastoralist Women in the East and Horn of Africa.

5. Pastoralist and Land, Land Tenure (2010) Administration and Use in Pastoral Areas of Ethiopia, International institute of Rural Reconstruction, Africa Regional Center, 26 PO Box 6687,00800 , Nariobi Kenya, Ethiopia Country Office P. Box 7931, Addis Ababa Ethiopia.

6. Peter D Little, Roy Behnke, John McPeak, Getachew Gebru (2010) Future Scenarios for Pastoral Development in Ethiopia, 2010-2025 Report Number 2 Pastoral Economic Growth and Development Policy Assessment, Ethiopia, March.

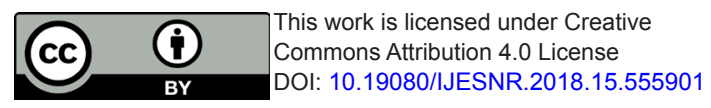

Your next submission with Juniper Publishers will reach you the below assets

- Quality Editorial service

- Swift Peer Review

- Reprints availability

- E-prints Service

- Manuscript Podcast for convenient understanding

- Global attainment for your research

- Manuscript accessibility in different formats

( Pdf, E-pub, Full Text, Audio)

- Unceasing customer service

Track the below URL for one-step submission

https://juniperpublishers.com/online-submission.php 